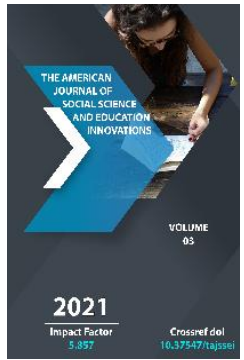

\title{
The Term "Hikmat" , ("Wisdom") Is Interpreted By Khoja Ahmad Yassavi And His Followers
}

Islombek Sultonalievich Mannopov

Lecturer, Doctor Of Philosophy In Philology, (PhD) Fergana State University, Uzbekistan

Journal Website:

http://usajournalshub.c om/index,php/tajssei

Copyright: Original content from this work may be used under the terms of the creative commons attributes 4.0 licence.

\section{ABSTRACT}

After Khoja Ahmad Yassavi, creation in his style continued until the early twentieth century. Ahmad Yassavi and his followers discussed the use of the term "Hikmat", "wisdom" in reference to a particular form of poetry.

\section{KEYWORDS}

Wisdom, tradition of wisdom writing, followers of Yassavi, Yassavi sect, "Devoni Hikmat", didacticphilosophical content, aphorism.

\section{INTRODUCTION}

The work containing the wisdom of Khoja Ahmad Yassavi is called "Devoni Hikmat". This work has been considered sacred by the Turkic peoples for centuries and is still read and studied as a reliable source. 
The emergence of poems called "Hikmat" , "wisdom" is directly related to the personality and activities of Khoja Ahmad Yassavi. Yassavi called the poetic pandnoma he recited "Hikmat", "wisdom" There are verses in the "Devoni Hikmat" that prove that wisdom is a pandnoma poem composed by Ahmad Yassavi:

The slave Khoja Ahmad mad said this on the Day of Judgment,

He wisely spread it among the people...[1, 114]. This meaning is hidden behind the words "wisely" above.

Poems called "Wisdom" played an important role in the literary, spiritual and enlightenment life of our people. Wisdom in research "moderate level of thinking skills; correct knowledge gained through experience, which is realized by application; The right word; the most perfect of all; wisdom is the army of Allah, through which Allah strengthens the heart of the saint; mystical poems are called wisdom. Wisdom is a short word, a parable, with a subtle meaning that corresponds to knowledge, wisdom, philosophy, mystery, reason; science that deals with the state, appearance, and mood of an object; a useful short word on morality and truth; Obedience to Allah; harmony of mind, speech and action"[2].

F.Koprulu writes: "From the 10th century onwards, religious and mystical works were called wisdom" [3].

\section{THE MAIN FINDINGS AND RESULTS}

The meaning of the word wisdom is interpreted in some interpretations of the Qur'an as consistency, that is, the unity of word and deed. "He gives wisdom (useful knowledge) to whomever He wills" [4] [5]. “My
Lord, send among them a Messenger from among themselves, who will recite to them your verses, and teach them the Book and Wisdom (Qur'an and Hadith), and purify them"(2/129). This verse states that the prophet in question was Muhammad Mustafa. Turkish scholar E.M.Hamdi Yazir states in his commentary that the word wisdom is a word with many meanings. Wisdom in the general sense represents the name of all beautiful knowledge and useful work. He cites more than twenty meanings of the word wisdom. Wisdom is finding the right direction in word and deed; both knowledge and practice, that is, the artistic application of what one knows; knowledge and jurisprudence; the ability to comprehend the origin of all objects and phenomena in existence; The best understanding of the judgments of Allah; know by following; to create, invent, innovate (for the benefit of human beings); the orderly placement of each item in the asset; striving for beautiful and right deeds; to try to resemble the great Creator in politics as far as human power is concerned (the relationship of wisdom and authority); To have the morality of Allah (to behave); Observing the commands of Allah and obeying Him unconditionally; Obedience to Allah; wisdom is a light through which only false temptation and true status can be distinguished; draw accurate and quick conclusions; to tell the truth, the truth; the last stop of the silence and bliss of the spirits; unreasonable reference; To take the side of truth in all cases; religion and world order; laduniy ilm; all of the above.

The first scholars to study the Devonian Wisdom used the poems in it under the name of Wisdom.[7]

When discussing the application of the term "wisdom" to a particular form of poetry, the 
first source of this phenomenon is "Devoni Hikmat". The poems called "Hikmat", "wisdom" were commented on by Ahmad Yassavi in "Devoni Hikmat". It is not possible to draw the correct conclusion about the true meaning of "wisdom" without referring to this source. In his "Devoni Hikmat”, Ahmad Yassavi describes "Hikmat”, "wisdom” as follows:

1. It is clear from the call "Say Wisdom" that saying wisdom is a divine command, inspired by:

O'ttuz to'rtda olim bo'lub, dono bo'Idim, «Hikmat ayt» deb, Subhon aydi, go'yo bo'ldum...

Or:

Sekkizimda sekiz yondin yo'l ochildi, «Hikmat ayt» deb boshlarimga nur sochildi...

Thirty-four became a scholar and became wise, "Tell me wisdom," said Subhan, as if I was...

Or:

At eight o'clock the road opened, "Tell me wisdom" shone on my head...

The above meaning is also meant when he says, "I have said four thousand four hundred wisdoms, the true decree."

2. It is emphasized that the content of the Qur'an and hadith is expressed in wisdom: Meni hikmatlarim farmoni Subhon, O‘qub bilsang hama ma’noyi Qur’on.

The decree of my wisdom Subhan, If you know how to read, it means the Qur'an Or:
Meni hikmatlarim koni hadisdur,

Kishi bo'y eltmasa, bilgil xabisdur.

The source of my wisdom is hadith,

If a person does not obey, he is knowingly evil

3. Wisdom is a divine, universal knowledge:

Hikmat birlan ul adamdin bor ayladi,

O'n sakkiz ming qomug' olam hayron erur.(8gb.)

With wisdom he became a man,

Eighteen thousand people are amazed. (P. 89)

4. There are verses that emphasize that wisdom is the source of knowledge and wisdom, of love:

Qul Xoja Ahmad, bu hikmatni kimga aytding,

Orifmen deb xaloyiqg‘a o'qub yoyding.

Slave Khoja Ahmad, to whom did you tell this wisdom,

You read it to the people as Orifmen

Or:

Oshiq bo'lub hikmat aydi qul Xoja Ahmad,

Sidqi birlan eshitganga yuz ming rahmat.

The slave Khoja Ahmad, who fell in love and said wisdom,

Thank you so much for listening

5. As the name of the poems in "Devoni Hikmat":

Sulton Xoja Ahmad Yassaviy aydi bu hikmatni tamom,

Eshitsun deb jumla-jahon, dunyoni solib ketoram. 
Sultan Khoja Ahmad Yassavi said that this wisdom is complete,

I'll leave the world, the world, to hear it.

6. There are many lines that encourage us to read, recite, and even write proverbs:

Meni hikmatlarim dono eshitsun,

Vale nasriy bitib maqsudg'a yetsun.

May my wisdom hear me wisely,

Because let the prose end and aim

7. Wisdom is a priceless word, so there are motives to encourage appreciation, not to tell the ignorant. Ahmad Yassavi praises wisdom through metaphors and expressions such as "pearl", "honey", "jewel deposit".

8. Saying wisdom has become a habit for Yassavi dervishes:

Siri birlan so'zlarlar, tilga hikmat tuzarlar, Ishq birlan jon kezarlar, rangi sarig‘ darveshlar. (8ob)

Words with secrets, wisdom with language,

They live with love, yellow dervishes. (8op)

He also used the words "word," "point," and "inspiration" in the Devonian Wisdom, which is similar to the meaning of wisdom. In Devoni Hikmat, there are passages that indicate that wisdom is the product of inspiration. For example, "Haqdin ilhom rafiq bol", "Qirq ettimda etti yoqdin ilhom etti", "ilhom keldi, chin quloqqa oldim mano".

Thus, Ahmad Yassavi began to recite poems called wisdom. He himself called these poems Wisdom in the Devonian Wisdom. These poems of his are the result of divine inspiration, and it can be said that he is a guardian, a sage, a lover, in a word, the subtle meaningful words, sincere feelings of a perfect man in the form of a poem. Its thematic content is wide and constitutes an enlightenment-enlightenment content. Wisdom is also a worldly knowledge, and wisdom is the etiquette of Yassavi.

The tradition of telling and writing wisdom, which began in the twelfth century, lasted until the nineteenth century. Among them, Suleyman Bagirgani, Kamal Sheikh Iqani, Shams Uzgendi, Kul Ubaydi, Khudoydod, Azim Khoja stand out from other followers in terms of size and weight.

Wise poets call their poems, written in the Yassavi style and spirit, in accordance with tradition, 'wisdom'. They acknowledge that their poems are wisdom. For example, the 16th century sage poet Ubaydi:

Hikmat ahlidek agarchi aytadur hikmat vale,

Qul Ubaydiy bor durur sharmanda o'z guftoridin[8].

Wisdom, though wise men say,

Slave Ubaydi is ashamed of his words[8].

he calls his poems wisdom. The 19th century sage poet Azim Khoja also unequivocally states that his Yassavi poems are wise:

Miskin Azim hikmat aytdi, munglug' bo'lub,

Ka'ba, Ravza firoqida qong'a to'lub.

Poor Azim was wise, he was sad,

The Ka'bah and Ravza are full of blood.

\section{CONCLUSION}

Yassavi's followers did not mean didacticphilosophical, aphoristic poems, but "Devoni Hikmat" and poems written in imitation of it. Wisdom became a special genre of poetry in 
The American Journal of Social Science and Education Innovations (ISSN - 2689-100x)

Published: April 30, 2021 | Pages: 258-263

the XII-XIX centuries. One of the current issues of our literature is to conduct research on the genre features of the so-called "wisdom" poems, which entered our classical poetry with the work of Khoja Ahmad Yassavi.

\section{REFERENCES}

1. Yassaviy A. Devonian wisdom. Tashkent: Literature and Art, 1992. -p.114.

2. Hasanov N. D. Sultan Ahmad Khazini's work "Javohirul abror min amvojil bihor" and its scientific and historical value in Yassavi studies, vol. dis ... Tashkent: 1999. p.47. Uludag S. Sufism of Sufi terms. Istanbul: Kabalci, 1995 .. Toychiev U. Literary types and genres. Three volumes, 2 vols. Epos. Tashkent: FAN, 1992. - p.6869.; Haqqul I. Wisdom and perception. Tashkent: Manaviyat, 1998. - p.148-149.

3. Köprülü F. Türk edebiyatında ilk mutasavvıflar. DiB yayınları. Ank.: 1991. - p. 119.

4. The Holy Quran. Uzbek annotated translation. The author of the translation and commentary is Alouddin Mansur. Tashkent: Cholpon, 1992. Surat al-Baqara, verse 269.

5. E. M. Hamdi Yazir. Hak dini Kuran dili 2. Istanbul: Zehrayeyin, 2017. -p. 204-225.

6. That source. -pp. 204-225.

7. See: M. Fuod Koprulu. Turk edebiyatinda ilk mutasavviflar. - Ankara: Diyanet iş̧leri Başkanlığı yayınları,1991. - p. 467. Abdurauf Fitrat. Investigations on the poets of the Yassavi school // Education and teacher, 1928. №5.

8. Borovkov A. Essays on the history of the Uzbek language. (Definition of the Khikmat language by Ahmad Yassevi). Oriental studies, V. Moscow: Nauka, 1973. - pp.229.

9. Kulliyoti Ubaydiy. FASHI, manuscript, inv. №8931. - p.356.
10. Sabirdinov A. ASKAR KASIMOV IN THE UZBEK POETRY OF THE XX CENTURY THE ROLE AND IMPORTANCE OF CREATION //Конференции. - 2020.

11. Gafurovich S. A. Analysis Of The Poem" Autumn Dreams" By Abdulla Oripov //The American Journal of Social Science and Education Innovations. - 2021. - T. 3. - №. 01. - C. 556-559.

12. Abdupattoev M. T. Unusual Connections As Forming Literary Text //The American Journal of Social Science and Education Innovations. - 2021. - T. 3. - №. 02. - C. 177182.

13. Каримов, У. (2017). ИНФОКОМТЕХНОЛОГИИ (ИКТ) ФОРМИРОВАНИЕ ДУХОВНЫХ ХАРАКТЕРИСТИК ЛИЧНОСТИ. In Перспективные информационные технологии (ПИТ 2017) (рр. 1160-1163).

14. Mannopov I. S. THE ISSUE OF AUTHORSHIP OF THE POETICS IN DIVANI HIKMAT //Theoretical \& Applied Science. - 2020. №. 9. - C. 411-414.

15. Sultonalievich M. I. YASSAVI LITERATURE AND ITS EMERGENCE //ANGLISTICUM. Journal of the Association-Institute for English Language and American Studies. 2020. - T. 9. - №. 8. - C. 26-33.

16. Oripova, G. (2019). UZBEK POETRY AND THE WORLD LITERATURE IN THE YEARS OF INDEPENDENCE. Scientific Journal of Polonia University, 32(1), 116-120.

17. Oripova Gulnoza Murodilovna. (2019). THE PECULIARITIES OF VAZN METER IN UZBEK POETRY OF THE INDEPENDENCE PERIOD. International Journal of Anglisticum. Literature, Linguisitcs and Interdisciplinary Studies. Volume: 8 /Issue:2/. - Macedonia, 2019. -P.33-39.

18. Murodilovna O. G. Melody and musicality in Lirycs //ACADEMICIA: An International 
Multidisciplinary Research Journal. - 2020. - T. 10. - №. 11. - C. 656-664.

19. Oripova G. M., Tolibova M. T. Q. Composition Of Modern Uzbek Stories //The American Journal of Social Science and Education Innovations. - 2021. - T. 3. №. 03. - C. 245-249.

20. Oripova, G. (2020, December). RHYTHM AND MYTHING IN LYRICAL GENRE. In Конференции.

21. Abdurashidovich K. A. Motivation and National Character of Foolishness in Uzbek Literature //ANGLISTICUM. Journal of the Association-Institute for English Language and American Studies. - 2018. - T. 7. - №. 4. - C. 47-51.

22. Qayumov A. CREATING OF A NATIONAL CHARACTER THROUGH MEANS OF LITERATURE //Theoretical \& Applied Science. - 2018. - №. 1. - C. 235-240.

23. Qayumov A. NATIONALITY: YESTERDAY AND TODAY //Конференции. - 2020.

24. Akhmadjonova O. A. Symbolic And Figurative Images Used In The Novel "Chinar" //The American Journal of Social Science and Education Innovations. - 2021. - T. 3. - №. 03. - C. 389-392.

25. Normatova D. E. PECULIARITIES OF ANTHROPOCENTRISM AND HUMANISM OF THE SOCIO-PHILOSOPHICAL THOUGHT OF WESTERN EUROPE IN THE ERA OF RENAISSANCE //Scientific Bulletin of Namangan State University. - 2019. - T. 1. №. 5. - C. 168-173.

26. Mashrapova, G. A. (2021). The Role Of Narrator In The Structure of The Artistic Fiction. The American Journal of Social Science and Education Innovations, 3(03), 378-383

27. Abdurakhmonova, M. M., ugli Mirzayev, $M$. A., Karimov, U. U., \& Karimova, G. Y. (2021). Information Culture And Ethical Education
In The Globalization Century. The American Journal of Social Science and Education Innovations, 3(03), 384-388.

28. Karimov, U., \& Ergasheva, D. (2020). EDUCATIONAL ISSUES IN THE PERIOD OF AMIR TEMUR AND TEMURIDS. Теория и практика современной науки, (5), 18-20.

29. Mashrapova, G. (2020, December). A UNIQUE IMAGE IN THE STORIES OF SHUKUR KHOLMIRZAYEV. In Конференции

30. Mukhammadjonova Guzalkhan. The image of a creative person in the poetry of Erkin Vohidov. ACADEMICIA: An International Multidisciplinary Research Journal. Volume : 10, Issue : 11, November. - India, 2020.

31. SABIRDINOV A. Sketches to the novel "Night and day" by Chulpan //Scientific journal of the Fergana State University. 2019. - T. 1. - №. 6. - C. 119-120. 